\title{
COMPRESSED ELEMENTS WITH A VARIABLE IN LENGTH STIFFNESS EQUILIBRIUM FORM STABILITY DETERMINATION
}

\author{
Shkurupiy Oleksandr ${ }^{1 *}$, Mytrofanov Pavlo 2 , Davydenko Yuriy ${ }^{3}$, Hajiyev Muhlis Ahmed ogly ${ }^{4}$ \\ ${ }^{1}$ Poltava National Technical Yuri Kondratyuk University https://orcid.org/0000-0003-1487-1037 \\ ${ }^{2}$ Poltava National Technical Yuri Kondratyuk University https://orcid.org/0000-0003-4274-1336 \\ ${ }^{3}$ Poltava National Technical Yuri Kondratyuk University $\underline{\text { https://orcid.org/0000-0002-6562-0046 }}$ \\ ${ }^{4}$ Azerbaijan Architecture and Construction University https://orcid.org/0000-0001-6782-0941 \\ Corresponding author E-mail: shbm@ukr.net
}

\begin{abstract}
One of the most powerful modern methods of calculating complex building structures is the finite element method in the form of a displacement method for discrete systems, which involves the creation of a finite element model, that is, splitting the structure into separate elements within each of which the functions of displacements and stresses are known. On the basis of the displacement method and the methods of iterations and half-division, an algorithm for stability calculation of the first kind equilibrium form of compressed reinforced concrete columns with hinged fixing at the ends, considering the stiffness changing has been developed. The use of the above methods enables to determine the minimum critical load or stress at the first bifurcation and their stability loss corresponding form. The use of matrix forms contributes to simplification of high order stability loss equation. This approach enables to obtain the form of stability loss that corresponds to the critical load.
\end{abstract}

Keywords: equilibrium form, compressed reinforced concrete columns, software complex, stability loss equation

\section{ВИЗНАЧЕННЯ ФОРМИ РІВНОВАГИ СТИСНУТИХ ЗАЛІЗОБЕТОННИХ ЕЛЕМЕНТІВ ЗІ ЗМІННОЮ ПО ДОВЖИНІ ЖОРСТКІСТЮ}

\author{
Шкурупій О.А. ${ }^{1 *}$, Митрофанов П.Б. ${ }^{2}$, Давиденко Ю.О. ${ }^{3}$, Гаджієв М.А. ${ }^{4}$ \\ 1, 2, 3 Полтавський національний технічний університет імені Юрія Кондратюка \\ ${ }^{4}$ Азербайджанський університет архітектури і будівництва \\ *Адреса для листування E-mail: shbm@ukr.net
}

\begin{abstract}
Одним з найбільш потужних сучасних методів розрахунку складних будівельних конструкцій є метод скінченних елементів в формі методу переміщень для дискретних систем, який передбачає створення скінченно-елементної моделі, тобто розбиття конструкції на окремі елементи у межах кожного 3 яких відомі функції переміщень та напружень. Метод скінченних елементів також передбачає формування та розв'язування системи лінійних алгебраїчних рівнянь порядок якої обумовлений кількістю невідомих вузлових переміщень. Розроблено алгоритм розрахунку стійкості першого роду форми рівноваги стиснутих залізобетонних колон з шарнірним закріпленням на кінцях, з урахуванням зміни жорсткості, на основі методу переміщень разом з методами ітерацій і повинного ділення. Використання вищеописаних методів дозволяє визначити мінімальне критичне навантаження або напруження при першій біфуркації та їх втрати стійкості відповідної форми. Використання матричних форм сприяє спрощенню рівняння втрат стійкості високого порядку. Такий підхід дозволяє отримати форму втрат стійкості, що відповідає критичному навантаженню. Описані вище особливості розрахунку таких конструкцій обумовлюють необхідність у використанні потужностей сучасних ПК, що у свою чергу потребує автоматизації розрахункових процесів у вигляді закінчених програмних комплексів та систем. На базі кафедри будівельної та теоретичної механіки Полтавського національного технічного університету імені Юрія Кондратюка були розроблені програмні утиліти, які реалізують взаємопов’язані задачі оцінювання міцності та надійності будівельних конструкцій та їх елементів.
\end{abstract}

Ключові слова: форма рівноваги, стиснуті залізобетонні колони, програмний комплекс, рівняння втрати стійкості. 


\section{Introduction}

There are various methods for calculating the stability of the equilibrium form of discrete systems, due to the large volume of computations associated with the solution of the analytical condition for the equilibrium stability loss. The solution of the analytical condition for the compressed discrete systems equilibrium stability loss, which has high orders, and the stability loss form critical load definition, are very important problems to be solved.

The algorithm for calculation of equilibrium stability loss form of compressed discrete systems of the first kind by the displacement method in combination with the methods of iterations and bisection with examples is given in [6]. It is implemented in the software package "Persist" for a PC in Windows OS.

To solve engineering tasks this computer program is implemented in a modern compiler, contains several subroutines that are combined and presented in the form of the same software complex.

\section{Review of research sources and publications}

The solution of the problem of calculating the analytical condition for the compressed discrete systems equilibrium stability loss, which has high orders, and the determination of the corresponding stability loss form critical load, generated a large number of methods by many mathematicians (Krylov, Laverier, Danilevsky, Jacobi (iterations) etc.).

\section{Definition of unsolved aspects of the problem}

When calculating the first kind equilibrium stability form of compressed reinforced concrete columns with hinged fixing at the ends, considering the stiffness changing (damage to the column sections) provided that the initial modulus of elasticity is constant; it is assumed the necessity of solving the stability loss equation which is non-linear transcendental and, as it is known, does not have an analytical solution $[1-4$, $7-12$ ]. In addition, these equation elements are complex mathematical dependencies, which contain Zhukovsky functions in their composition, which also greatly complicates the equation solution.

The purpose of the work is to develop an algorithm and software for the PC in Windows OS, which enables students and engineers to automate calculations of stability of equilibrium forms of compressed discrete systems.

In recent years, the software complex "Persist" has been tested and successfully implemented in the training of specialists for the building industry $[5,6]$.

\section{Problem statement}

The calculation of the compressed discrete system on the stability of the equilibrium form actually reduces to the solution of the difficultly described nonlinear transcendental equation, which is the equation of stability loss. The difficulty lies in the absence of analytical solution of such equation due to the presence of complex functions of Zhukovsky, which have transcendental functions in their structure. Such solution can be performed only with the use of numerical methods. This problem of calculating the analytical condition for compressed discrete systems equilibrium stability loss, as well as the determination of the critical load of the stability form, is proposed to be solved by displacement, iteration and bisection methods, which enables to significantly simplify calculations.

\section{Basic material and results}

It has been obtained stability loss equation of the equilibrium form of reinforced concrete columns with hinged fixing at the ends considering stiffness changing due to the displacement's method in expanded form provided that compression and stretch deformations are ignored $[5,6,13]$.

Output data:

$$
\begin{aligned}
& h_{1}=m_{1} l ; h_{2}=m_{2} l ; h_{3}=m_{3} l ; h_{4}=m_{4} l ; \\
& E=\mathrm{const} \neq \infty ; \\
& i_{j}=\left(\frac{E J}{l}\right)_{j}(j=\overline{1.4}) .
\end{aligned}
$$

It has been calculated: the value of the minimum critical longitudinal force $N_{c r}^{\min }$ at stability loss of the first kind equilibrium form considering damages on any column sections (Figure 1).

It has been accepted, $i=i_{01}, J=J_{01}$ and it has been expressed all rigid stiffness on the bend of the column sections due to these parameters and the first section length $h_{1}=m_{1} l$.

$$
\begin{aligned}
& i_{01}=\frac{E J_{01}}{h_{1}} ; \quad i_{12}=\frac{E J_{12}}{h_{2}} ; \\
& i_{23}=\frac{E J_{23}}{h_{3}} ; \quad i_{34}=\frac{E J_{34}}{h_{4}},
\end{aligned}
$$

where

$$
J_{01}=J ; \quad J_{12}=C_{2} J ; \quad J_{23}=C_{3} J ; \quad J_{34}=C_{4} J .
$$

The values of the coefficients of the rigid stiffness ratio on bend, expressed through the first section rigid stiffness, are equal to:

$$
\begin{array}{ll}
K_{01}=\frac{i_{01}}{i}=1 ; & K_{12}=\frac{i_{12}}{i}=\frac{C_{2} m_{1}}{m_{2}} ; \\
K_{23}=\frac{i_{23}}{i}=\frac{C_{3} m_{1}}{m_{3}} ; & K_{34}=\frac{i_{34}}{i}=\frac{C_{4} m_{1}}{m_{4}} .
\end{array}
$$

The rigid stiffness on each of the four sections bend is expressed as:

$$
\begin{aligned}
& J_{01}=J ; \quad i_{01}=K_{01} i ; \quad i_{12}=K_{12} i ; \\
& i_{23}=K_{23} i ; \quad i_{34}=K_{34} i .
\end{aligned}
$$

Considering the above expressions, the rigid stiffness final value on the bend of each of the four sections is:

$$
\begin{aligned}
& i_{01}=\frac{E J_{01}}{m_{1} l} ; \quad i_{12}=\frac{E J_{12}}{m_{2} l} ; \\
& i_{23}=\frac{E J_{23}}{m_{3} l} ; \quad i_{34}=\frac{E J_{34}}{m_{4} l} .
\end{aligned}
$$


Thus, this approach enables to change the flexural stiffness of each section of the column (see calculation scheme, Figure 1) by varying the moments of inertia at the corresponding axes, provided that the initial elastic modulus remains constant.

Determination of the minimum critical force $\left(N_{c r}^{\min }\right)$ is obtained using the displacement method expanded form $[5,6,9]$.

It is recorded the displacement method equilibrium equation in accordance with the column calculation scheme (Figure 1).

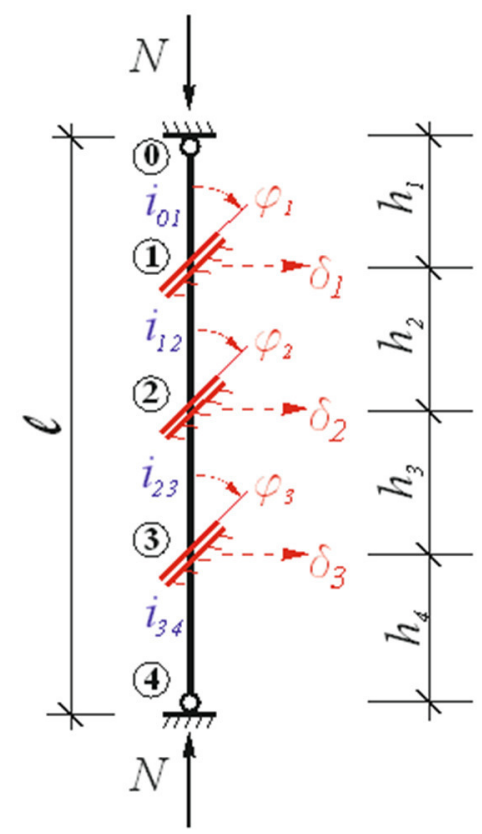

Figure 1 - The column calculation scheme

Displacement method equilibrium equations takes the form (Figure 2).

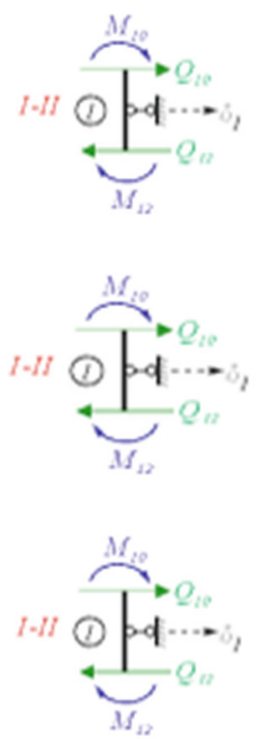

Figure 2 - Calculation schemes of the column nodes

$$
\left\{\begin{array}{l}
M_{10}+M_{12}=0 \\
Q_{10}-Q_{12}=0 \\
M_{21}+M_{23}=0 \\
Q_{21}-Q_{23}=0 \\
M_{32}+M_{34}=0 \\
Q_{32}-Q_{34}=0
\end{array}\right.
$$

The same equations are recorded in a matrix form:

$$
r \cdot \vec{Z}=0,
$$

where $r$-stiffness matrix of column sections elements (reactive forces in fictitious joints from unknown vector $\vec{Z}$ unit values)

$$
r=\left(\begin{array}{llllll}
r_{11} & r_{12} & r_{13} & r_{14} & r_{15} & r_{16} \\
r_{21} & r_{22} & r_{23} & r_{24} & r_{25} & r_{26} \\
r_{31} & r_{32} & r_{33} & r_{34} & r_{35} & r_{36} \\
r_{41} & r_{42} & r_{43} & r_{44} & r_{45} & r_{46} \\
r_{51} & r_{52} & r_{53} & r_{54} & r_{55} & r_{56} \\
r_{61} & r_{62} & r_{63} & r_{64} & r_{65} & r_{66}
\end{array}\right) .
$$

According to the reciprocity of reactions theorem $r_{i k}=r_{k i}(i, k=\overline{1,6})$. Therefore, the stiffness matrix is represented only by the values of its upper triangle parameters.

$$
r=\left(\begin{array}{cccccc}
r_{11} & r_{12} & r_{13} & r_{14} & r_{15} & r_{16} \\
& r_{22} & r_{23} & r_{24} & r_{25} & r_{26} \\
& & r_{33} & r_{34} & r_{35} & r_{36} \\
& & & r_{44} & r_{45} & r_{46} \\
& & & & r_{55} & r_{56} \\
& & & & & r_{66}
\end{array}\right) .
$$

$\vec{Z}$ - vector of the displacement method unknown in accordance with the column calculation scheme (Figure 1)

$$
\vec{Z}=\left\{\begin{array}{l}
Z_{1} \\
Z_{2} \\
Z_{3} \\
Z_{4} \\
Z_{5} \\
Z_{6}
\end{array}\right\}=\left\{\begin{array}{l}
\varphi_{1} \\
\varphi_{2} \\
\varphi_{3} \\
\varphi_{4} \\
\varphi_{5} \\
\varphi_{6}
\end{array}\right\}
$$

The system of equilibrium equations (6) is a system of linear algebraic homogeneous equations that has the following properties:

a) the system has a zero (trivial) solution (the physical content of the vector $\vec{Z}=0$, that is, the column maintains a straightforward form - there is no equilibrium form stability loss);

b) the system has no zero solution if $\operatorname{det}(r)=\mathrm{D}=0$. In this case, there is a problem of eigenvalues, that is, system (6) has many solution roots. Physical content: vector $\vec{Z} \neq 0$ (there are angular and linear displacements of the system nodes, indicating the appearance of 
a new deformation form - the longitudinal bending, i.e., the system loses the equilibrium form stability (the first kind stability loss). Thus, $\operatorname{det}(r)$ there is an analytical condition for the equilibrium stability loss (stability loss equation), the solution of which is able to determine $N_{c r}^{\min }$ with the methods of iterations and half-division.

Compressed column equilibrium form stability loss equation has the following general form

$$
\operatorname{det}(r)=D=\left|\begin{array}{llllll}
r_{11} & r_{12} & r_{13} & r_{14} & r_{15} & r_{16} \\
& r_{22} & r_{23} & r_{24} & r_{25} & r_{26} \\
& & r_{33} & r_{34} & r_{35} & r_{36} \\
& & & r_{44} & r_{45} & r_{46} \\
& & & & r_{55} & r_{56} \\
& & & & & r_{66}
\end{array}\right|=0
$$

Equilibrium form stability loss equation (11) is a transcendental equation, that has many solution roots. To determine the smallest value of the critical load (critical longitudinal force $N_{c r}^{\mathrm{min}}$ ), numerical methods of iterations and half-division are used.

In the equation (11), the compressive force $N$ is an unknown value and is expressed by Zhukovsky functions $(\alpha, \beta, \gamma, \bar{\alpha}, \bar{\gamma}, \ldots)$, which are expressed through the parameter $t$, which in turn is expressed in longitudinal force $N$ terms.

By preliminary calculating the relationship between the parameters $t$ in the compressed column through the base parameter $t_{0}$, it is determined the critical parameters $t$ in each compressed element, and then their critical longitudinal forces and critical load.

$$
\begin{aligned}
& t_{j}^{2}=\left(\frac{N l^{2}}{E I}\right)_{j} ; \quad t_{j}^{2}=\left(\frac{N l}{i}\right)_{j} ; \\
& N_{j, c r}=\left(\frac{t^{2}{ }_{c r} E I}{l^{2}}\right)_{j}=\left(\frac{t^{2} \cdot i}{l}\right)_{j} .
\end{aligned}
$$

In this case, the critical forces in each section of the column should be the same. It is $N_{c r}^{\mathrm{min}}$ for the column.

The equation (14) is calculated if the stiffness of the system elements changes. To do this, it is needed to set the appropriate correlation of the relationship parameters: $m_{1}, m_{2}, m_{3}, m_{4}$ and $C_{1}, C_{2}, C_{3}, C_{4}$.

So, for the given calculation scheme of the column (Figure 1), the relationship between the parameters $t$ of each section is:

As the base parameter it is taken $t=t_{01}$, then:
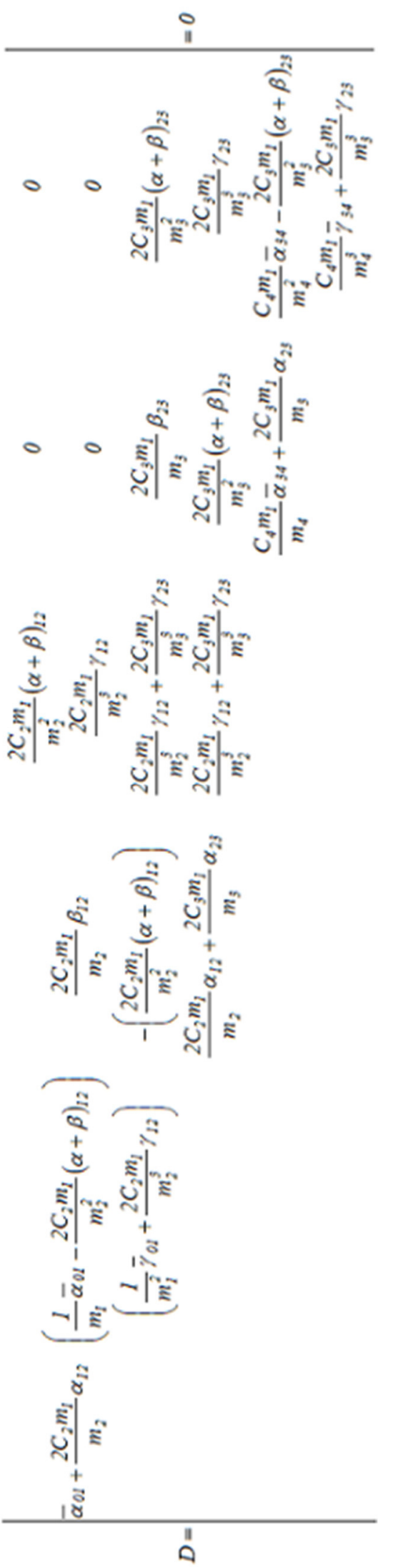


$$
\begin{gathered}
t=t_{01}=t_{1}=\sqrt{\frac{N \cdot h_{1}}{i_{01}}}=\sqrt{\frac{N \cdot m_{1} \cdot l}{i}} ; \\
t_{12}=t_{2}=\sqrt{\frac{N \cdot h_{2}}{K_{12} \cdot i}}=\sqrt{\frac{N \cdot m_{2}^{2} \cdot l}{C_{2} \cdot m_{1} \cdot i}} ; \\
t_{23}=t_{3}=\sqrt{\frac{N \cdot h_{3}}{K_{23} \cdot i}}=\sqrt{\frac{N \cdot m_{3}^{2} \cdot l}{C_{3} \cdot m_{1} \cdot i}} ; \\
t_{34}=t_{4}=\sqrt{\frac{N \cdot h_{4}}{K_{34} \cdot i}}=\sqrt{\frac{N \cdot m_{4}^{2} \cdot l}{C_{4} \cdot m_{1} \cdot i}} ; \\
\zeta_{2}=\frac{t_{12}}{t}=\frac{t_{2}}{t}=\frac{m_{2}}{m_{1}} \sqrt{\frac{1}{C_{2}}} ; \\
\zeta_{3}=\frac{t_{23}}{t}=\frac{t_{3}}{t}=\frac{m_{3}}{m_{1}} \sqrt{\frac{1}{C_{3}}} ; \\
\zeta_{4}=\frac{t_{34}}{t}=\frac{t_{4}}{t}=\frac{m_{4}}{m_{1}} \sqrt{\frac{1}{C_{4}}} ;
\end{gathered}
$$

Thus,

$$
t_{01}=t_{1} ; t_{12}=\zeta_{2} \cdot t ; t_{23}=\zeta_{3} \cdot t ; t_{34}=\zeta_{4} \cdot t .
$$

To determine $N_{c r}^{\min }$ (calculation of the equation of stability loss of equilibrium form (4)) it is used the software complex "Persist" specially developed by the authors for the corresponding output data $\left(m_{j}, C_{j}, \zeta_{j}\right)$, which algorithm is based on numerical methods of iterations and half-division $[5,6]$. The iteration method enables to determine the subinterval with the minimum value of the base critical parameter $t_{c r}$, and the halfdivision method to specify its value to the predefined accuracy.

At the same time, since everything was expressed due to the basic rigid stiffness $i$ and the length of the $\operatorname{rod} l$, the final value $N_{c r}^{\min }$ should be multiplied by the rigid stiffness $i$ and divided by the length of the rod $l$.

It is considered a calculation example, when the stiffness of all column elements is constant (Figure 1). In this case, the source data are:

$$
\begin{gathered}
h_{1}=h_{2}=h_{3}=h_{4}=\frac{l}{4} ; E=\text { const } \neq \infty ; \\
J=J_{01}=J_{12}=J_{23}=J_{34} ; i=i_{01}=i_{12}=i_{23}=i_{34} \\
C_{1}=C_{2}=C_{3}=C_{4}=1 ; m_{1}=m_{2}=m_{3}=m_{4}=\frac{1}{4} .
\end{gathered}
$$

The relation between the parameters $t$ are written as:

$$
\begin{gathered}
t_{0}=t_{01}=t_{12}=t_{23}=t_{34}, \\
\zeta_{1}=\zeta_{2}=\zeta_{3}=\zeta_{4}=1 .
\end{gathered}
$$

The stability loss equation for such output data is:
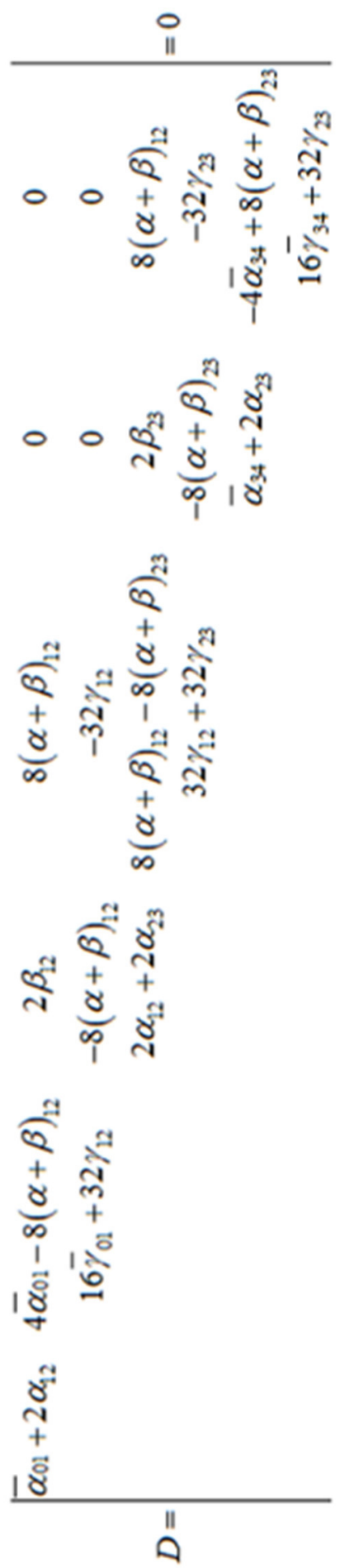
To further calculating the column for the equilibrium form stability we use the software complex "Persist" (Figure 3-10).

Here is a step-by-step algorithm for entering input data and necessary parameters for the software complex "Persist":

1. It is entered the relation for the parameter $t$ :

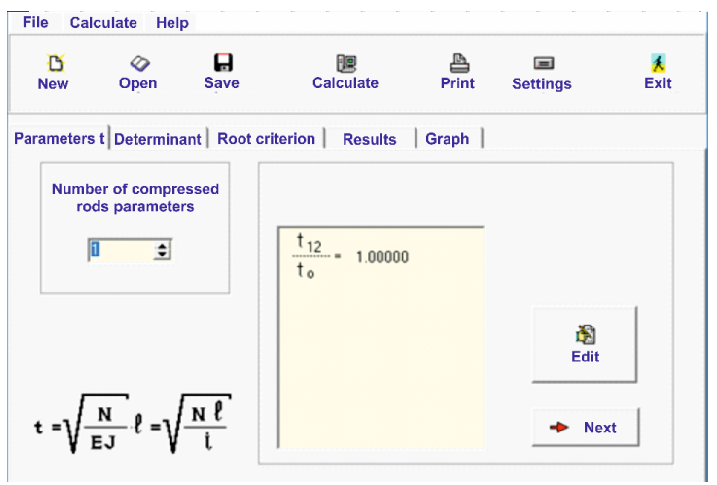

Figure 3 - Recording correlations for parameters $t$

2. It is entered the elements of the upper triangle of equilibrium stability loss equation (28).

For example, it is entered an element $r_{11}$. To do this, it is necessary to select element 1.1, and press the "Build" button:

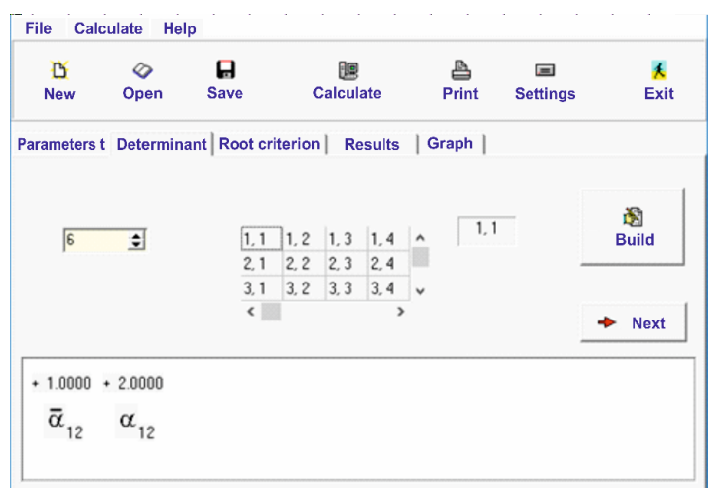

Figure 4 - Entering values for an element $r_{11}$

At the next step, it is entered the expression value for the element in the menu item "Determinant", the button "Build". Similarly, it is introduced all other elements of the upper triangle (28).

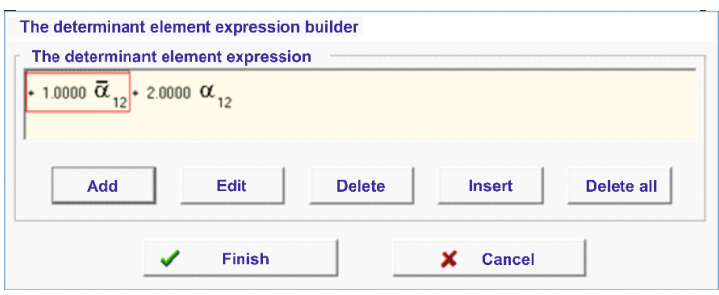

Figure 5 - Writing the expression for the element $r_{11}$

Expression for an element $r_{66}$

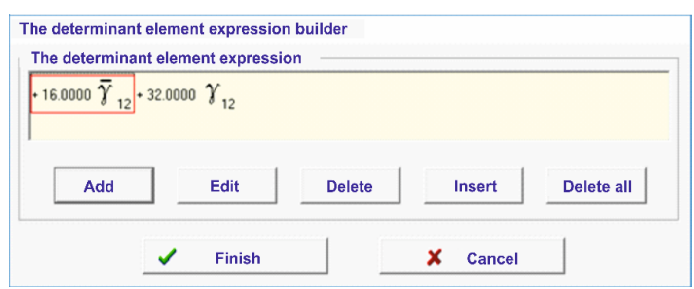

Figure 6 - Writing the expression for the element $r_{66}$

3. It is chosen the desired accuracy for calculating the root of the stability loss equation $t_{0}$ (the determinant minimum value, $10^{-4}$ ). Also, it is set the base parameter initial value (0), and also basic parameter to changing step $t_{0}(0,1)$. If necessary, this step can be reduced.

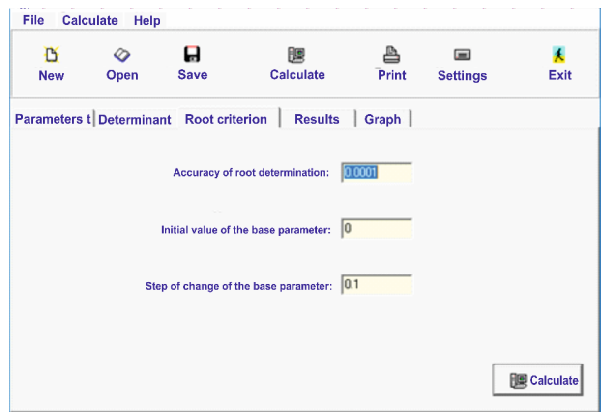

Figure 7 - Configuring accuracy for calculate the stability loss equation root

4. In the menu bar, press the "Calculate" button and go to the "Results" tab:

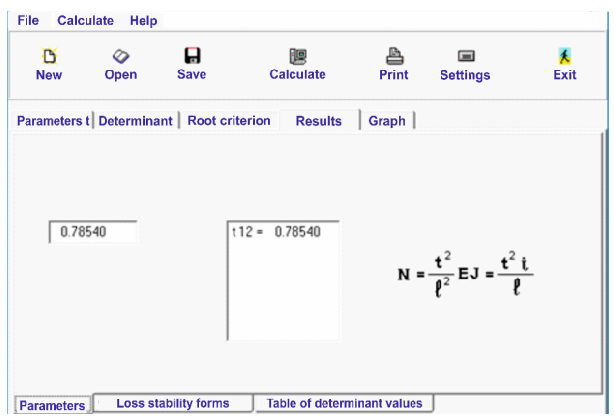

Figure 8 - View of the calculation results

If necessary, activate the tab "Table of determinant values", and it can be viewed step-by-step calculation results by iteration and half-division methods:

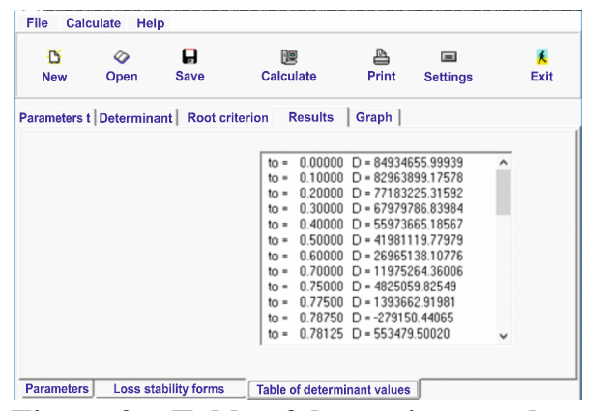

Figure 9 - Table of determinant values

If necessary, by activating the "Graph" tab, it can be viewed a step-by-step graphic representation of the stability loss equation solution (28): 


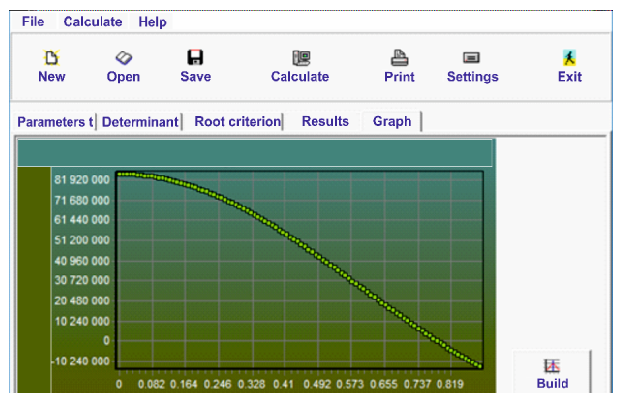

Figure 10 - Graphical representation of the stability loss equation solution

This $N_{c r}^{\min }$ is equal to:

$$
N_{c r, j}^{\min }=\left(\frac{\left(t_{c r} \cdot n\right)^{2} \cdot i}{\ell}\right)=\frac{(0,7854 \cdot 4)^{2} \cdot i}{\ell}=\frac{3,1416^{2} \cdot i}{\ell} .
$$

It should be noted that the dimension of the critical force depends on the given dimensions of the stiffening on bend $i$ and the rod length $l$.

\section{Conclusions}

The method of calculation and algorithm is developed, which are implemented in the software complex "Persist". The program com-plex has been successfully implemented in the educational process in the study of the discipline "Structural Mechanics" at the educational-scientific Architecture and Civil Engineering Institute of Poltava National Technical Yuri Kondratyuk University. This software can be used by students and engineer-designers for engineering calculations, including calculating the first kind equilibrium form stability of compressed reinforced concrete columns with hinged fixing at the ends, considering the stiffness changing.

\section{References}

1. Hartmann, F. (1985). The Mathematical Foundation of Structural Mechanics. Berlin, Heidelberg: Springer. https://doi.org/10.1007/978-3-642-82401-2

2. Lacarbonara, W. (2013). Nonlinear Structural Mechanics. Boston: Springer.

https://doi.org/10.1007/978-1-4419-1276-3

3. Hjelmstad, K.D. (2005). Fundamentals of Structural Mechanics. Boston: Springer.

https://doi.org/10.1007/b101129

4. Hulse, R. \& Cain, J. (1991). Structural Mechanics. London: Palgrave.

https://doi.org/10.1007/978-1-349-11897-7

5. Shkurupiy, O., Mytrofanov, P. \& Masiuk, V. (2018). Calculation of The Stability of the Form of Equilibrium of Discrete Systems. International Journal of Engineering \& Technology, 7(3.2), 401-407.

http://dx.doi.org/10.14419/ijet.v7i3.2.14561

6. Шкурупій, О.А. (2015). Стійкість форми рівноваги та динаміка дискретних систем. Полтава: ПолтНТУ.

7. Киселев, В.А. (1980). Строительная механика. Сnециальный курс. Москва: Стройиздат.

8. Смирнов, А.Ф., Александров, А.В., Лащеников, Б.Я., Шапошников, Н.Н. (1981). Строительная механика. Динамика устойчивости сооружений. Москва: Стройиздат.

9. Баженов, В.А., Перельмутер, А.В., Шишов, О.В (2008). Будівельна механіка. Комп'ютерні технологіі. Київ: «Каравела».

10. Фадеев, Д.К., Фадеева, В.Н. (1960). Вычислительные методы линейной алгебры. Москва: Физматлит.

11. Баженов, В.А., Дехтярник, В.А., Дехтярник, Е.С. (1998). Будівельна механіка. Динаміка споруд. Київ: I3MH.

12. Smith, P. (2001). An Introduction to Structural Mechanics. Palgrave Macmillan.

13. Severyn, V., Pashchenko, A. \& Mytrofanov, P. (2018) Probabilistic Analysis of Structures Under Snow Load. International Journal of Engineering \& Technology, 7(3.2), 339-342.
1. Hartmann, F. (1985). The Mathematical Foundation of Structural Mechanics. Berlin, Heidelberg: Springer. https://doi.org/10.1007/978-3-642-82401-2

2. Lacarbonara, W. (2013). Nonlinear Structural Mechanics. Boston: Springer.

https://doi.org/10.1007/978-1-4419-1276-3

3. Hjelmstad, K.D. (2005). Fundamentals of Structural Mechanics. Boston: Springer.

https://doi.org/10.1007/b101129

4. Hulse, R. \& Cain, J. (1991). Structural Mechanics. London: Palgrave.

https://doi.org/10.1007/978-1-349-11897-7

Shkurupiy, O., Mytrofanov, P. \& Masiuk, V. (2018). Calculation of The Stability of the Form of Equilibrium of Discrete Systems. International Journal of Engineering \& Technology, 7(3.2), 401-407.

http://dx.doi.org/10.14419/ijet.v7i3.2.14561

6. Shkurupiy, O.A. (2015). Stability of equilibrium and $d y$ namics of discrete systems. Poltava: PoltNTU.

7. Kyselev, V.A. (1980). Structural mechanics. Special course. Moscow: Stroyizdat.

8. Smyrnov, A.F., Aleksandrov, A.V. \& Lashchenikov, B.Y. \& Shaposhnikov N.N. (1981). Structural mechanics. Dynamics and stability of structures. Moscow: Stroyyzdat.

9. Bazhenov, V.A., Perel'muter, A.V. \& Shyshov, O.V. (2008). Structural Mechanics. Computer Technology. Kyiv: Karavela.

10. Faddeev, D.K. \& Faddeeva, V.N. (1960). Computational methods of linear algebra. Moscow: Fyzmatlyt.

11. Bazhenov, V.A. Dekhtyarnik, V.A. \& Dekhtyarnik, Ye.S. (1998). Structural Mechanics. Dynamics of structures. Kyiv: IZMN.

12. Smith, P. (2001). An Introduction to Structural Mechanics. Palgrave Macmillan.

13. Severyn, V., Pashchenko, A. \& Mytrofanov, P. (2018). Probabilistic Analysis of Structures Under Snow Load. International Journal of Engineering \& Technology, 7(3.2), 339-342. 